\title{
The Influence of Leadership Style, Compensation and Motivation on Employee Performance at PT Garuda Indonesia Region IV Makassar
}

\author{
Nurdjanah Hamid ${ }^{1}$, Wahda ${ }^{2}$, Annisa Aulia Yuniar ${ }^{3}$ \\ \{nununghamid17@gmail.com'; iwarasjid@gmail.com²; annisaay@yahoo.com³ \\ Universitas Hasanuddin, Makassar, Indonesia ${ }^{1,2,3}$
}

\begin{abstract}
This research aims to analyze the effect of leadership style, compensation and motivation on employee performance at PT Garuda Indonesia Region IV Makassar. This study used a simple random sampling technique, a sample of 63 respondents from the PT Garuda Indonesia Head Office was used. The research data was obtained from a questionnaire (primary), literature study, and direct interviews with relevant parties according to the purpose of the study. The analysis technique used PLS data analysis consisting of structural models, measurement models, and Sobel models. The results illustrated that leadership style as well as compensation had a significant and positive effect on employee performance. However, motivation, leadership style through motivation, and compensation through motivation have a positive but not significant impact on employee performance.
\end{abstract}

Keywords: Leadership Style, Compensation, Motivation, and Employee Performance.

\section{Introduction}

Human resources are considered elements that determine what steps taken by a company in pursuing its goals. In the world of aviation services, quality human resources have become a necessity. Increasing business competition requires employee performance in each company to anticipate changes in the internal and external environment. If it is developed regularly and planned, it will be able to bring to a certain social level [1]. This is also done with the fact that a company cannot be separated from human labor. In order to achieve a company's progress, the potential within employees must be developed. PT Garuda Indonesia (Persero) believes that the most valuable assets it possesses are employees. Therefore, this company is maintaining how to keep employee performance good.

The goals set by a company can be achieved if the utilization of its human resources is done in a way that favor the company. In the world of aviation services, quality human resources have become a necessity. Increasing business competition requires employee performance in each company to anticipate changes in the internal and external environment. If it is developed regularly and planned, it will be able to bring to a certain social level [1]. This is also done with the fact that a company cannot be separated from human labor; although it has a considerable financial capital and advances technological advancement, human forces are still required to run a business. In order to achieve a company's progress, the potential within employees must be developed. PT Garuda Indonesia (Persero) believes that 
the most valuable assets it possesses are employees. Therefore, this company is maintaining how to keep employee performance good.

PT Garuda Indonesia (Persero) presents the best full-service flight services. Currently, there are 82 fleets operating for 33 domestic and 18 international destinations, including Asia, Australia, and Europe. PT Garuda Indonesia (Persero) receives an IATA Operational Safety Audit (IOSA) certification due to its high-level concern over its safety. This can prove that the airline has met international standards in the field of safety and security. PT Garuda Indonesia (Persero) has opened many branches throughout Indonesia, has 13 overseas representative offices, and has 45 representative offices in cities in Indonesia, and one of them is located in Makassar, namely the PT Garuda Indonesia Region Branch Office IV. In this regard, companies in the millennial era have very big challenges in managing their human resources, which are changing rapidly. Human resources as assets should be maintained and developed in order to provide a maximum contribution that can affect work motivation.

In an effort to realize the company's goals, one of which is to have employees who have good performance. Performance is a goal-oriented process that is directed at ensuring that organizational processes are in place to maximize the performance of employees, teams, and ultimately the organization. Employee performance can be measured by how many targets can be achieved, how much achievement is achieved, and the ability to complete the jobs that exist in the company. The better the performance of employees will affect the achievement and value in the company. Therefore, performance is a major factor in a company's success. Good performance will produce positive things, and bad performance will have a negative impact on the company.

Based on observations made by researchers, there are problems regarding the performance of employees at the Headquarters of PT Garuda Indonesia region IV Makassar. Employee performance has declined since 2016. This is due to an unfulfilled wish of employees who have worked for more than five years to be promoted as permanent employees. Besides, the low benefits provided to employees who excel in achieving the targets set by the company. This issue led to the employee discipline as indicated by the lack of employees who were difficult to attend on time according to the specified schedule, which caused delays in work that should have been completed on the same day. In addition, there are employees who cannot do work in accordance with predetermined rules. Therefore, issues regarding employee performance must be considered by company leaders.

One of the things that influence employee performance in achieving company goals is regarding leadership style. In this process, the function of a leader has a very important role in determining the organization of a company. The function of the leader is not just to provide guidance and direction to employees, but the most important thing is how a leader is able to provide a clear vision and mission or direction where the organization will go to get results in accordance with the initial purpose of the establishment of the company.

A process in influencing, motivating, and making people contribute to the efficacy and the achievement of an organization is defined as leadership (House et al., In Yukl [2]). The ability to influence that possessed by a leader will determine the way employees are used to achieve work results. A leader will be considered good if he wants to accept changes, willing to accept criticism and suggestions from subordinates openly, and often pay attention to their welfare. Tailoring the system and process in an organization that caters to the needs of individuals, groups, and organizations is the strategy that should be taken by the organizational leader in order to influence the behavior in an organization.

This leadership style often becomes an obstacle for employees in carrying out daily tasks and activities. Leaders are required to understand the motives of their employees because 
motives are based on a desire to satisfy various types of needs, which in turn will affect employee behavior and performance. A leader is an example, role model, idol, and coach for all members of the organization he leads in improving work. The manifestations of leadership include behavior, attitudes, character, and policies possessed by the leader [3]. In the research conducted by Yayan Alfian Nugraha [4] regarding the Effect of Leadership Style on the Motivation of the Employees of PT. Serang branch General Finance proves that there is a substantial impact between leadership style variables on employee work motivation. So to achieve the company's vision, it takes the role of an effective leader in providing motivation to employees so that they are always able to compete with competitors.

Every employee who works at a company has a purpose and objective. The purpose of employees working in a company is to fulfill their needs. Whereas the employee's goal, in general, would be to expect achievement compensation in the form of compensation. According to Handoko [5] compensation is anything that employees receive as compensation for their work. Because basically, people work also want to earn money to meet their daily needs; for this reason, an employee starts to appreciate hard work and increasingly shows loyalty to the company, and that's why the company rewards employees' work performance by giving compensation. Past investigation conducted by Rendy Putrayasa, regarding the impact of compensation on work motivation and staff performance at PT. Asuransi Jiwasraya shows that compensation has a substantial impact on work motivation, which means the level of employee motivation depends on the level of financial compensation. Motivation contributes significant impact on employee performance, meaning that the performance result of employees depend on the work motivation aspect.

The phenomenon of compensation observed at PT Garuda Indonesia (Persero) shows that the implementation of compensation has not been realized properly. The problem can be seen from the high workload, where PT Garuda Indonesia has now taken over the operational management of Sriwijaya Air and NAM Air. This was realized in the form of an Operational Cooperation (KSO) conducted by PT Citilink Indonesia with PT Sriwijaya Air and PT NAM Air. Therefore, Garuda Indonesia Group is currently launching the "One Gate Facility" service for Garuda Indonesia, Citilink, Sriwijaya Air and Nam Air flight ticket sales transactions at the Garuda Indonesia branch office in Makassar [6]. However, the application is not balanced with compensation according to employee needs. This can be shown from the gap that the standard salary and employee benefits are not evenly distributed and do not refer to the work professionalism standards. Besides giving work incentives to employees is not based on work results, but adjusted according to work hours, which causes employees less eager to carry out their work. In addition to the standard salary gap and work incentives that are not in accordance with the professional capabilities of employees, compensation that is still low according to employees is the provision of unfair work benefits, mainly benefits in the form of providing work insurance, as well as transportation and meals. This includes granting work severance to employees who resign or have finished their term of service, where severance received is not in accordance with desired performance and expectations. As a result of compensation that does not meet the expectation of the employee causing employee performance to decline. This can be seen from employees who are unable to provide services in accordance with the achievement of work goals, lack of achievement in carrying out their work, not achieving targets and work realization, and employee welfare lacking attention from management.

Another factor that can affect employee performance is work motivation. Victor Vroom (in [7]) suggests the theory of expectations, which states that motivated employees will make an effort to achieve goals and get a good performance appraisal. The employee's performance 
depends not only on his ability to complete the task but also on the work motivation he has. This is supported by research conducted by Rahman [8], which shows that there is a substantial impact between work motivation on staff performance.

The company should focus on employee motivation in order to positively contribute on the ability of the company to achieve its goals. Highly motivated employees are an important organizational asset for consistently achieving maximum work results. The hierarchy of needs theory from Abraham Maslow [9] identifies five general types of motivational needs, namely physiological needs, needs for security, social needs, needs for appreciation, and needs for self-actualization. Previous research conducted by Asriyanto [10] in his research proved that the results showed that the influence of motivation could improve employee performance. With high motivation, employees will work for the company more actively in carrying out their work. Conversely, by providing low work motivation, employees do not have the spirit to work, give up easily, and have difficulty in completing their work.

According to information obtained from Rahayu [6], Pahala Nugraha Mansury said that management had devised a strategy, both long term, and short term. In the short term or quick win, Garuda will focus on improving services (Service Level Improvement), optimizing flight routes (Routes Optimization), increasing utilization of digital channels (Channel Optimization with Focus on Digital to become IT-Based Airline), and systematic increase in company revenue (Enhance Revenues Management System). With this design, employees are expected to be able to improve their performance. This needs to be accompanied by continuous improvement in management, organization, systems, products, expertise and professionalism of employees, and so on. In every activity the company cannot be separated from the success of the resources which are the main factors. Employees are not merely objects in achieving goals, but also become subjects or actors. They can be planners, implementers and controllers who always play an active role in realizing the company's goals, and have thoughts, feelings and desires that can affect their attitudes towards work.

Based on the background stated above, the authors conducted a study by taking the title "The Effect of Leadership Style, Compensation and Motivation on Employee Performance at PT Garuda Indonesia Region IV Makassar".

\section{Literature Review}

\subsection{Leadership Style}

Leadership Style is a series of characteristics that are used by leaders to influence subordinates in order to achieve the objective of the organization [11]. Moreover, Rivai defines leadership style as a pattern of behavior and strategies that are preferred and often applied by a leader according to [11].

\subsection{Compensation}

According to Rivai in Septawan [12], compensation is something that is received by employees as a substitute for the contribution of their services to the company. Sastrohadiwiryo in Septawan [12] argues that compensation is compensation for services or remuneration given by the company to the workers because the workers have contributed energy and thoughts for the progress of the company to achieve the stated goals. 


\subsection{Motivation}

Mathis and Jackson [13] suggest that motivation is the desire in a person that causes the person to act. People usually act for a reason, which is to achieve a goal. Motivation is an impulse that is regulated by purpose. Robbins and Judge [14] define motivation as a process that explains the strength, direction, and perseverance of someone in an effort to achieve goals.

\subsection{Performance}

Mangkunegara [15] defines actual performance comes from the word job performance and is also called actual performance or actual achievements that have been achieved by an employee. There are so many definitions or definitions of performance that are said by experts, but all of them have some common meaning and the meaning of that performance.

While Moeheriono (2014) argues that performance is the measure of activities or policies implementation that has been achieved when working towards organizational goals, objectives, vision, and mission through its strategic plans.

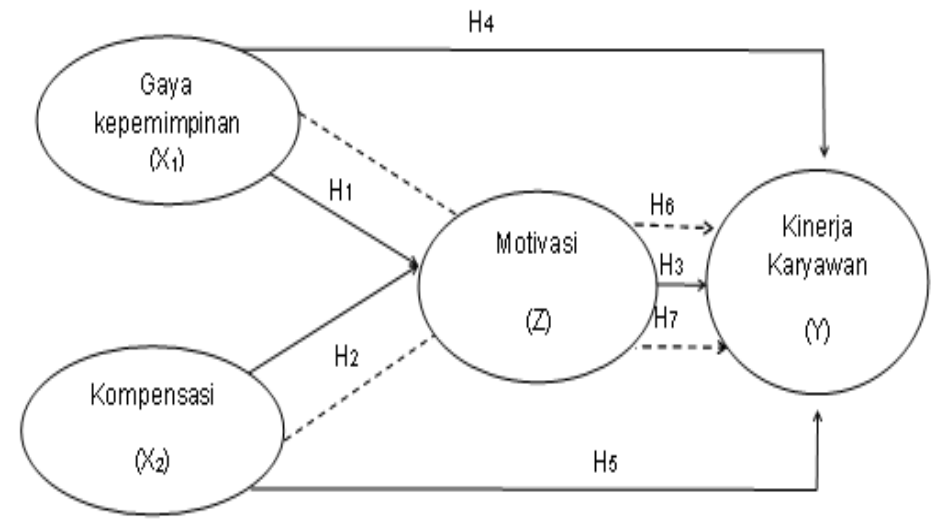

Fig 1. Conceptual Framework

Note:

$\mathrm{X} 1=$ Leadership Style

$\mathrm{X} 2=$ Compensation

$\mathrm{Z} \quad=$ Motivation

$\mathrm{Y} \quad=$ Employee performance

H1 = Leadership style positively and significantly influence motivation

$\mathrm{H} 2=$ Compensation positively and significantly influence motivation

$\mathrm{H} 3=$ Motivation positively and significantly influence performance

$\mathrm{H} 4=$ Compensation positively and significantly influence motivation

H5 = Compensation positively and significantly influence performance

H6 = Leadership style positively and significantly influence motivation

H7 = Compensation positively and significantly influence motivation

$\rightarrow \quad=$ Direct impact

---- Indirect impact 


\section{Methodology}

\subsection{Research Sites}

This research was conducted at the Office of PT Garuda Indonesia (Persero), located on Jl. Slamet Riyadi No. 6, Makassar City, South Sulawesi.

\subsection{Population and Sample}

The population in this research were all employees of PT Garuda Indonesia (Persero) Region IV Makassar, with a total of 144 employees. From this population, samples were drawn to be used in this study as respondents. The study used a probability sampling method with a simple random sampling technique so that the number of samples was 63 people.

\subsection{Measurement}

The leadership style variables adopted in this study consisted of indicators: instruction, consultation, participation, delegation [16]. The compensation variable included: salary, incentives or bonuses, indirect financial compensation, insurance, benefits [17]. Motivational variables measured: physiological needs, needs for security, social needs, needs for the appreciation of self-actualization needs [9] while the measured performance variables are: Work quality, work quantity, timeliness, effectiveness, independence [18].

\subsection{Data analysis technique}

Data collection in this research was carried out through questionnaires containing a number of statements along with a Likert scale answer form column with a range of 1-5. The data analysis technique was carried out by structural equation modeling - the method of partial least square (SEM-PLS), through three stages: the measurement model test model, the structural model test, and the hypothesis testing.

\section{Discussion}

\subsection{Validity and Reliability Test}

Table 1. Validity and Reliability Test

\begin{tabular}{cllll}
\hline No & Variables/Indicators & $\begin{array}{c}\text { Correlation Coefficient } \\
\text { (r) }\end{array}$ & $\begin{array}{l}\text { Cronbach's } \\
\text { Alpha }\end{array}$ & Description \\
\hline 1. & Leadership Style (X1) & & 0.712 & Reliable \\
& Leadership Style 1 & 0.763 & & Valid \\
& Leadership Style 2 & 0.468 & & Valid \\
& Leadership Style 3 & 0.372 & & Valid \\
& Leadership Style 4 & 0.823 & & Valid \\
& Leadership Style 5 & 0.848 & & Valid \\
\hline
\end{tabular}




\begin{tabular}{|c|c|c|c|c|}
\hline \multirow[t]{9}{*}{2.} & Compensation (X2) & & 0.925 & Reliable \\
\hline & Compensation 1 & 0.755 & & Valid \\
\hline & Compensation 2 & 0.709 & & Valid \\
\hline & Compensation 3 & 0.867 & & Valid \\
\hline & Compensation 4 & 0.849 & & Valid \\
\hline & Compensation 5 & 0.914 & & Valid \\
\hline & Compensation 6 & 0.919 & & Valid \\
\hline & Compensation 7 & 0.926 & & Valid \\
\hline & Compensation 8 & 0.965 & & Valid \\
\hline \multirow[t]{7}{*}{3.} & Motivation (Z) & & 0.844 & Reliable \\
\hline & Motivation 1 & 0.871 & & Valid \\
\hline & Motivation 2 & 0.872 & & Valid \\
\hline & Motivation 3 & 0.814 & & Valid \\
\hline & Motivation 4 & 0.721 & & Valid \\
\hline & Motivation 5 & 0.633 & & Valid \\
\hline & Motivation 6 & 0.871 & & Valid \\
\hline \multirow[t]{7}{*}{4.} & Performance (Y1) & & 0.876 & Reliable \\
\hline & Performance 1 & 0.900 & & Valid \\
\hline & Performance 2 & 0.835 & & Valid \\
\hline & Performance 3 & 0.666 & & Valid \\
\hline & Performance 4 & 0.900 & & Valid \\
\hline & Performance 5 & 0.737 & & Valid \\
\hline & Performance 6 & 0.860 & & Valid \\
\hline
\end{tabular}

Source: Processed Data 2019

In the table above, it can be seen that the Cronbach's Alpha value found in all variables shows a value $>0.6$, which means that all variables are reliable. Then the value of the correlation coefficient indicates a value $>0.3$, which means that all indicators that contain these variables are valid.

\subsection{Structural Model Test}

Table 2. $\mathrm{R}^{2}$ Value

\begin{tabular}{ccc}
\hline & R Square & $\begin{array}{c}\text { R Square } \\
\text { Adjusted }\end{array}$ \\
\hline $\mathrm{Y}$ & 0.55 & 0.527 \\
$\mathrm{Z}$ & 0.618 & 0.605 \\
\hline \multicolumn{2}{c}{ Source: Processed Data 2019 }
\end{tabular}

It can be seen that the value of $\mathrm{R}^{2}$ for the effects of $\mathrm{X} 1, \mathrm{X} 2$, and $\mathrm{Z}$ on $\mathrm{Y}$ is 0.55 . Meaning $55 \%$ of the diversity of employee performance variables is influenced by variables of leadership style, compensation and work motivation, while $45 \%$ of the diversity of employee performance variables is influenced by other variables not included in this study. 


\subsection{Hypothesis Test}

Table 3. Hypothesis Test

\begin{tabular}{|c|c|c|c|c|}
\hline & Original Sample (O) & $\begin{array}{l}\text { T Statistics } \\
(|\mathrm{O} / \mathrm{STDEV}|)\end{array}$ & P Values & Description \\
\hline $\mathbf{x} 1->y$ & 0.428 & 3.899 & 0.000 & H4 Accepted \\
\hline $\mathbf{x 1}->\mathbf{z}$ & 0.55 & 8.157 & 0.000 & H1 Accepted \\
\hline $\mathbf{x} 2->y$ & 0.277 & 2.821 & 0.005 & H5 Accepted \\
\hline $\mathbf{x} 2->\mathrm{z}$ & 0.327 & 5.135 & 0.000 & H2 Accepted \\
\hline \multirow[t]{2}{*}{$\mathbf{z}->\mathbf{y}$} & 0.182 & 1.418 & 0.157 & H3 Rejected \\
\hline & & $\begin{array}{l}\text { Indirect } \\
\text { Influence }\end{array}$ & & \\
\hline $\mathbf{x} 1->\mathrm{z}->$ & 0.1 & 1.378 & 0.169 & H6 Rejected \\
\hline $\begin{array}{c}\mathbf{y} \\
\mathbf{x} 2->\mathbf{z}-> \\
\mathbf{y}\end{array}$ & 0.059 & 1.204 & 0.229 & H7 Rejected \\
\hline
\end{tabular}

\subsection{Leadership style (X1) has a positive and significant effect on the motivation (Z) of PT Garuda Indonesia (Persero) Region IV Makassar}

From the R-square estimation results obtained, the $\mathrm{R}^{2}$ value of 0.58 means that $58 \%$ of the diversity of leadership style variables is influenced by motivation variables (H1 accepted). This means that motivation which is measured through five indicators namely physiological needs where the company provides salaries that meet basic needs every month as well as health insurance to employees, the need for a sense of security where the company gets a guarantee of work safety insurance and the existence of a security system owned by the company makes employees feel safe to work in the office, social needs where employees feel happy working at the company because of the harmonious working environment conditions, the need for rewards where the leader gives praise to employees when carrying out satisfying work assignments and self-actualization needs where the company gives employees the freedom to develop their full potential there is in the employee to be more advanced. Based on this research, it can be explained that work motivation is needed by an employee to achieve high-performance outputs. This is in accordance with the definition of Sutrisno [19] that leadership is a process of someone's activity to mobilize others by leading, guiding, influencing others to do something in order to achieve the expected results.

\subsection{Leadership style (X1) has a positive and significant effect on the performance of employees (Y) of PT Garuda Indonesia (Persero) Region IV Makassar}

From the results of the $\mathrm{R}$-square calculation, an $\mathrm{R}^{2}$ value of 0.575 is obtained, meaning $57.50 \%$ (H4 is accepted). This means that employee performance is measured through five indicators namely Work Quality, where employees are trying to achieve work targets according to those set by the company, Work quantity where employees always work with quality standards set by the company, Work time provisions where employees are trying to complete work on time, Effectiveness employees, are present on time in accordance with the 
specified schedule, and Independence in completing employee work is always thorough and careful to avoid mistakes.

Based on this research, it can be explained that with the leadership style adopted by the leader, it is expected that there is a harmonious communication relationship between the leaders and employees or between employees with one another to improve performance. This is in accordance with the definition of Alberthina Letlet, which states that in order to further improve employee performance for company success, it is necessary to use an effective leadership style.

\subsection{Compensation (X2) has a positive and significant effect on the motivation (Z) of PT Garuda Indonesia (Persero) Region IV Makassar}

Based on the results of hypothesis testing, it is known that compensation has a positive and significant effect on employee work motivation, this indicates that the better the compensation given by the company to employees will have a good impact on employee work motivation. Research conducted by Sagita Sukma [20] found that compensation has a significant effect on work motivation, meaning that the level of employee motivation depends on the level of financial compensation.

Motivation has a significant effect on employee performance, meaning that the level of employee performance depends on the level of motivation and work motivation, thus hypothesis 5 indicates that motivation has a significant effect on employee performance. Attention needs to be paid to employee compensation so that they are able to show their inner drive to work, and the company's responsibility to ensure that.

\subsection{Compensation (X2) has a positive and significant effect on the motivation (Z) of PT Garuda Indonesia (Persero) Region IV Makassar}

Based on the results of hypothesis testing, it is known that compensation has a positive and significant effect on employee performance. Catherine Nathania [21] found a positive and significant effect on employee performance, the same thing done by Nur Sasongko \& Ahyar Yuniawan that to improve employee performance, there needs to be attention to employee compensation. The better the compensation, the better the performance of employees at work.

\subsection{Motivation ( $Z$ ) has a positive but not significant effect on the performance of employees (Y) of PT Garuda Indonesia (Persero) Region IV Makassar}

From the calculation results obtained by the hypothesis test There is a positive influence of work motivation $(\mathrm{Z})$ on employee performance $(\mathrm{Y})$ of 0.327 which proves that Motivation (Z) has a positive but not significant effect on the performance of employees of PT Garuda Indonesia (Persero) Region IV Makassar (H3 rejected). Based on this research, it can be explained that there are still employees who are still not well motivated. This is indicated by the fact that there are still employees at PT Garuda Indonesia (Persero) Region IV Makassar who feel they lack appreciation from the company for their achievement of the targets set by the company that they have achieved where work motivation is needed by an employee to achieve high-performance outputs. Basically, motivation can encourage employees to do everything possible in carrying out their duties because they believe that with the success of the organization to achieve its goals and objectives, personal interests in members of the organization will be maintained. This is consistent with Vroom's theory of expectancy theory, 
which states that motivated employees will make maximum efforts to achieve goals and get a good performance appraisal.

\subsection{Leadership style (X1) through Motivation (Z) has a positive but not significant effect on the performance of employees of PT Garuda Indonesia (Persero) Region IV Makassar}

From the results of the calculation of the coefficient value of $\mathrm{X} 1$ to $\mathrm{Y}$ of 0.1 with $\mathrm{t}$ arithmetic $(1,378)$ which is smaller than 1.96 and p-value $(0.169)$ which is greater than 0.05 . This means that there is a positive influence between leadership style (X1) through Motivation $(\mathrm{Z})$ on employee performance $(\mathrm{Y})$ of 0.1 , but the influence formed is not significant (not real) at $\alpha=5 \%$. Hypothesis testing proves that the leadership style (X1) through motivation (Z) has a positive but not significant effect on employee performance (Y) of PT Garuda Indonesia (Persero) Region IV Makassar (H6 rejected). Based on this research it can be explained that there are still gaps in the treatment by leaders who are less fair towards their subordinates, and lack of attention, respect for the talents and potential of employees. So that, in this case, results in the inaccuracy of employees in carrying out their duties as it has become its obligation. Therefore the leader plays an important role in finding the best solution in addressing the problems above. This is consistent with the theory (House et al., In [2]) that Leadership Style is the ability of individuals to influence, motivate, and make others able to contribute to the effectiveness and success of the organization.

\subsection{Compensation (X2) through Motivation ( $Z$ ) has a positive but not significant effect on the performance of employees (Y) of PT Garuda Indonesia (Persero) Region IV Makassar}

From the calculation of the coefficient value of $\mathrm{Y}$ of 0.059 with $\mathrm{t}$ arithmetic (1.204) which is smaller than 1.96 and p-value $(0.229)$ which is greater than 0.05 . This means that there is a positive impact between compensation (X2) through motivation (Z) on employee performance $(\mathrm{Y})$ of 0.059 , but the effect formed is not significant (not real) at $\alpha=5 \%$. Hypothesis testing proves that Compensation (X2) through Motivation (Z) has a positive but not significant impact on employee performance (Y) of PT Garuda Indonesia (Persero) Region IV Makassar (H7 rejected). Based on this research, it can be explained that the implementation of compensation has not been realized properly. The problem can be seen from the high workload, where PT Garuda Indonesia has now taken over the operational management of Sriwijaya Air and NAM Air. This was realized in the form of an Operational Cooperation (KSO) conducted by PT Citilink Indonesia with PT Sriwijaya Air and PT NAM Air. Therefore, Garuda Indonesia Group is currently launching the "One Gate Facility" service for Garuda Indonesia, Citilink, Sriwijaya Air, and Nam Air flight ticket sales transactions at the Garuda Indonesia branch office in Makassar [6]. However, the application is not balanced with compensation according to employee needs. This can be shown from the gap that the standard salary and employee benefits are not evenly distributed and do not refer to the work professionalism standards. Besides giving work incentives to employees is not based on work results, but adjusted according to work hours, which causes employees less eager to carry out their work. This is in accordance with what Handoko [5] stated, compensation is everything received by employees as compensation for their work. 


\section{Conclusion}

Employee performance in work can be maximized if there is a good leadership style that is to inspire subordinates and always provide appropriate solutions to a problem. Leadership style through motivation has a positive but not significant impact on the performance of employees of PT Garuda Indonesia Region IV Makassar, meaning that employees do not feel valued for the achievement of their work. In addition, compensation through motivation has a positive but not significant impact on the performance of employees of PT Garuda Indonesia Region IV Makassar; it means that giving motivation without reciprocity from the company in the form of incentives and bonuses. Also, the promotion of positions to employees who excel and other benefits do not affect the performance of the employee. Based on the research results, also note that motivation has a positive but not significant impact on the performance of employees of PT Garuda Indonesia Region IV Makassar, meaning that employees will make maximum efforts to achieve their goals if they get a good and fair performance evaluation.

\subsection{Suggestion}

It is recommended that PT Garuda Indonesia Region IV Makassar, especially leaders, can maintain the quality of leadership style in the following ways: holding discussions with employees to expect suggestions from employees in decision making and policies. So that employees avoid uncomfortable feelings that will have a negative influence on employee performance. PT Garuda Indonesia Region IV Makassar must pay attention to giving compensation to employees. The firm should pay more attention to the suitability expected by employees so that what is needed by employees can be fulfilled. PT Garuda Indonesia Region IV Makassar can provide strong encouragement in order to provide strong motivation to employees, and cooperation between individual employees is realized so that organizational goals will be achieved. PT Garuda Indonesia Region IV Makassar to pay more attention to the timeliness of employees working at work, so that employee performance will be better. It is recommended that further research be expected to expand the object of research and not only in the Garuda Indonesia Region IV Makassar Office, but also in other offices, and can also be done at schools and universities.

\section{References}

[1] Wakerkwa, O.: "Peranan Sumber Daya Manusia dalam Meningkatkan Pembangunan Masyarakat di Desa Umbanume Kecamatan Pirime Kabupaten Lanny Jaya,” HOLISTIK, J. Soc. Cult. (2016)

[2] Yukl, G.: "Kepemimpinan dalam organisasi, Edisi kelima," Jakarta PT. Indeks (2010)

[3] Roscahyo, A.: "Pengaruh gaya kepemimpinan terhadap kinerja karyawan pada Rumah Sakit Siti Khodijah Sidoarjo,” J. Ilmu Ris. Manaj., vol. 2, no. 12, pp. 1-16 (2013)

[4] Nugraha, Y. A.: "Pengaruh Gaya Kepemimpinan Terhadap Motivasi Kerja Karyawan Pt General Finance Cabang Serang," Urnal Ilm. Revenue, vol. 2, no. 2, pp. 80-90 (2016)

[5] Handoko, T. H.: "Manajemen Personalia dan Sumber Daya Manusia BPFE." Yogyakarta (1998)

[6] Rahayu, I. R. S, "Strategi Garuda Indonesia Mengatasi Kerugian," 2018. [Online]. Available: https://www.inews.id/finance/bisnis/ini-strategi-garuda-indonesia-mengatasi-kerugian. [Accessed: 27-Feb-2018]

[7] As'ad, M.: "Psikologi industri, seri ilmu sumber daya manusia," Penerbit Lib. Yogyakarta (2004)

[8] Rahman, D.: "Pengaruh Kompetensi dan Kepemimpinan Terhadap Kinerja Karyawan Dengan 
Motivasi Sebagai Variabel Intervening (Studi Kasus Pada Karyawan Bagian Pabrik PT. Jember Indonesia)," (2014)

[9] Maslow, A. H.: Motivation and personality. Prabhat Prakashan (1981)

[10] Asriyanto, N. A.: "Pengaruh Motivasi Kerja dan Lingkungan Kerja terhadap Kinerja Karyawan CV. Kalika Intergraha di Semarang." Universitas Negeri Semarang (2013)

[11] Rivai, V., and Mulyadi, D.: "Kepemimpinan dan perilaku organisasi," Jakarta Raja Graf. Persada, (2003)

[12] Septawan: Manajemen Personalia dan Sumber Daya Manusia Yogyakarta (2014)

[13] Mathis, R. dan John Jackson, L.: "Hum. Resour. Manag. (Manajemen Sumber Daya)",(edisi 10) Terjem. Angelica, Penerbit Salemba Empat, Jakarta (2012)

[14] Robbins, S. P., and Judge, T. A "Perilaku Organisasi, Edisi Pertama, Cetakan Keempat belas." Jakarta: PT. Raja Grafindo Persada (2003)

[15] Mangkunegara, A. A. A. P.: Manajemen sumber daya manusia perusahaan. PT. Remaja Rosdakarya (2016)

[16] Hersey, P. and Blanchard, K.: "Manajemen perilaku organisasi," Erlangga. Jakarta (1982)

[17] Mathis, R. L., and Jackson, J. H.: "Human Resources Management, Edisi ke 10," Jakarta: Salemba Empat (2006)

[18] Dessler, G.: "MSDM, Jilid II, Jakarta: PT.” Indeks (2006)

[19] Sutrisno, H.: "Manajemen keuangan teori, konsep dan aplikasi," Yogyakarta: Ekonosia (2009)

[20] Haryani, S. S.: "Pengaruh kompensasi terhadap motivasi kerja dan kinerja (Studi pada karyawan PT. Telekomunikasi Indonesia, Tbk Malang),” J. Adm. Bisnis, vol. 25, no. 1 (2015)

[21] Nathania, C.: "Pengaruh Kompensasi Terhadap Kinerja Karyawan Pada PD Damai Motor Bandar Lampung," (2016) 